\title{
The Creation of a Japanese Writer for the Global Age The Case of Haruki Murakami
}

\section{Alona U. Guevarra}

Ateneo de Manila University

\section{Abstract}

The case of Haruki Murakami's rise to dominance in both the Japanese and global literary fields is truly exceptional. It is rare for a single author to introduce so much innovation in a literary field in his own lifetime. However, due to the fruitful combination of Murakami's own talent, the cooperation of his literary collaborators, Murakami, Inc., the advancement in technology (i.e., the Internet) that has allowed Murakami to be in touch with his readers, and his exceptional understanding of English, Murakami has contributed much to Japan's contemporary literature in the age of global literature. In addition to these factors, it must be emphasized that Murakami's agency of transforming the conservative literary field of Japan into something more accessible to both the Japanese and the non-Japanese has made Murakami a force that has also transformed Japan's Post-World War, modern literary field into a field that is open to accommodate postmodern techniques in writing, reflective of its historical position or context and global in its reach.

\section{Keywords}

global literature, Haruki Murakami, Japanese Contemporary Literature, literary field 


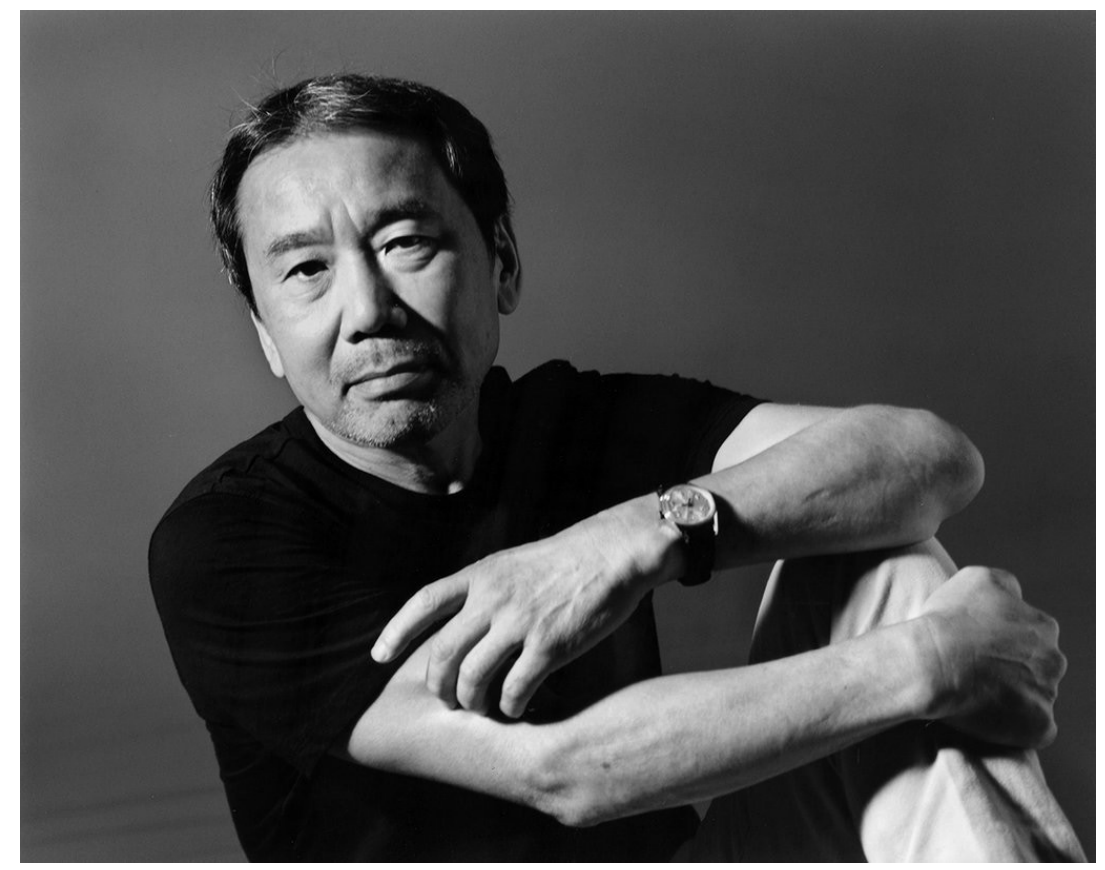

Fig. 1. Haruki Murakami's agency of transforming the conservative literary field of Japan into something more accessible to both the Japanese and the non-Japanese has made him a force that has also transformed Japan's Post-World War, modern literary field into a field that is open to accommodate postmodern techniques in writing; https://www. nytimes.com/ 

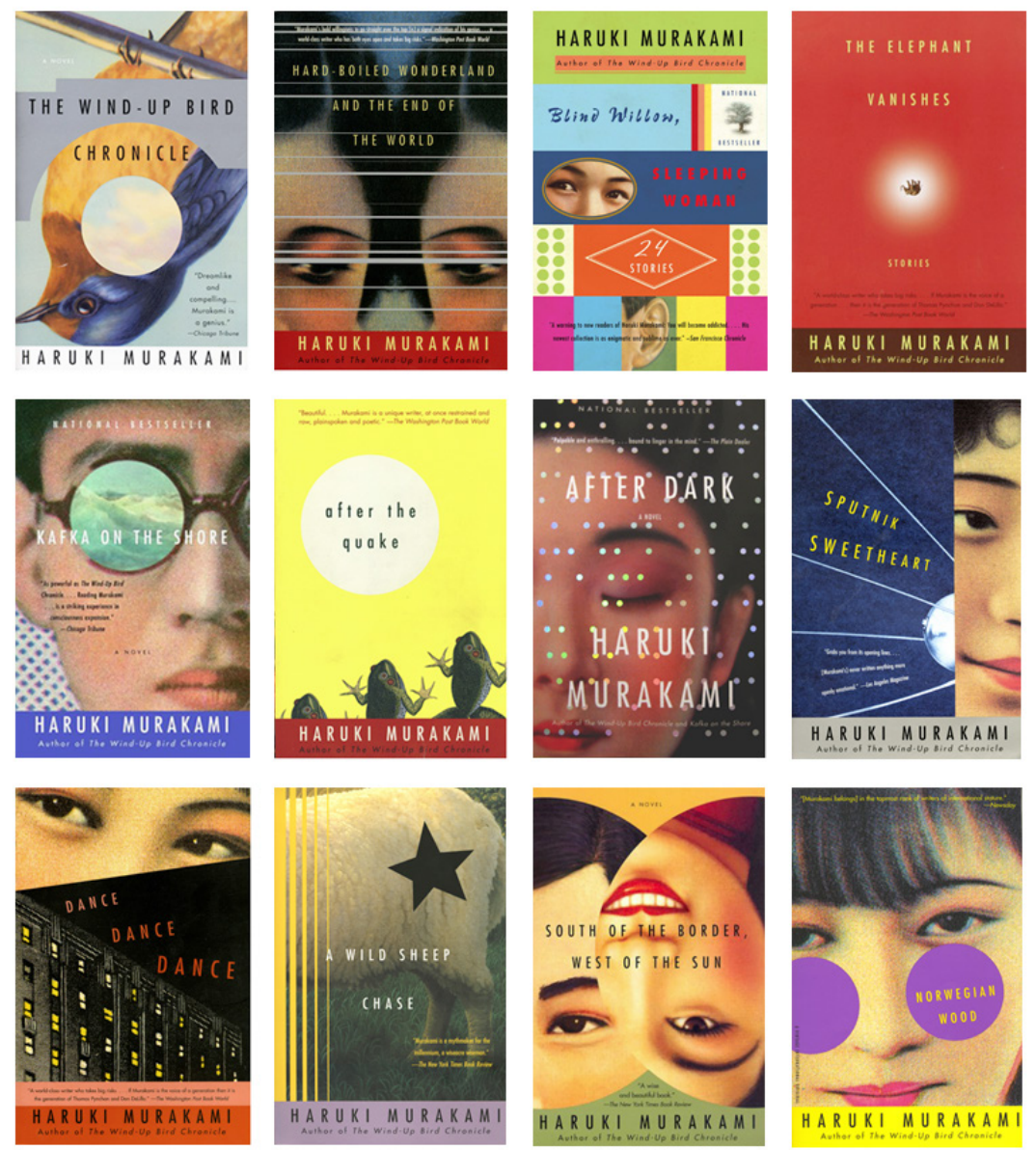

Fig. 2. Murakami paperback covers; https://images.app.goo.gl/tPJFsT4ne6Eq3Ung8 


\section{Haruki Murakami as a Global Writer}

The English-speaking world had its first taste of Haruki Murakami’s fiction back in 1990 when Plume (a division of Penguin) books published internationally its translation of Hitsuji o meguru boken ( $A$ Wild Sheep Chase [AWSC]). The novel has multiple references to American cultural figures and there is a clear indication that its writing style was inspired by Western writing, particularly that by the novelist, Raymond Chandler. As a result, AWSC did not have the cultural scent that would have easily pigeonholed the novel into the Asian/Oriental/Other classification in which the Western world would have placed texts from Japan and the rest of Asia. AWSC provided a sort of dilemma: it was neither here (Western) or there (Other). It was, in other words, a novel that had a very strong borderless quality that was and still is enigmatic.

How Murakami's fiction was introduced to the West, particularly in the contemporary literary center of New York, has now been a topic of interest since Murakami has become a canonized writer both nationally and internationally. Although Murakami got his break in Japan as the winner of the 22nd Gunzo Literary Prize in 1979 for his Kaze no uta o kike (Hear the Wind Sing) which later would be published by Tokyo's biggest publisher Kōdansha, Murakami began to accumulate symbolic capital when he broke into the American market.

In Louis Templado's Asahi Shimbun aptly titled article, "Teamwork Helped Haruki Murakami Break into American Scene,” he quotes Tetsu Shirai, a former deputy executive director at Kōdansha International Ltd. who said that the success of AWSC in the US was a product of the conscientious effort of the publisher Kōdansha International Ltd. to market a then "Japanese writer that the world has never heard of." The publisher put together a team of American veterans in the publishing industry: "[ $t]$ he translation, the editing, the publicity and the marketing strategy were all left to their judgment," according to Shirai.

The strategies that Murakami's American team initially used to introduce him in the US truly were so successful that those strategies continue to see Murakami through over two decades of publication in translation. 
Over the two decades of having his novels and short story collections translated into English, Murakami has never released a work that did not sell in the English-speaking market. He has developed very loyal readers overseas, while he and his literary collaborators have developed a good understanding of these readers. Recounting the initial strategies that Murakami's US collaborators made use of during the launch of $A$ WSC, Templado reports:

[p] ublicity was done New York style, with advance reading copies of the book (which [Alfred] Birnbaum originally titled "Adventures with a Sheep") sent to buyers, reviewers, movie industry people, authors, publishing firms, editors, friends and relatives a half year before the novel reached bookstore shelves. That explains how a NYT (New York Times) reviewer met Murakami right as soon as he stepped off the plane, before Shirai and (Elmer) Luke led him around the cocktail party circuit ("Teamwork Helped”).

Murakami's fresh talent, coming unexpectedly from a stiff Japanese literary field, along with the expertise of his supporters from the local and US literary fields (which can be referred to as Murakami, Inc.) is the formula of Murakami's success. This affirms what Pierre Bourdieu presents in his book The Rules of Art: Genesis and Structure of the Literary Field (1996) where he argues, through his study of Gustave Flaubert's career, that an author's success is not based on his individual talent alone but in the relations the author has within the literary field and the so-called "literary enterprises" that support his works (49). As the years passed, Murakami has established a literary style that capitalizes on almost formulaic surreal plots that loyal readers appear to not tire of.

With English as a primary global language, the extent of Murakami's readership, although not officially tallied, can safely be approximated to be in the millions. In 2016, the Facebook account that one of his American publishers Alfred A. Knopf maintained for him had more than 1.2 million followers worldwide. The hard work that Murakami, Inc. has carried out continues to succeed as there are a growing number of literary awards (what Bourdieu refers to as social capital) that the Japanese literati and international critics have bestowed upon Murakami's works. Recent examples of the 
latter include the Franz Kafka award in 2006, the Jerusalem prize in 2009, the International Catalunya Prize in 2011, and most recently, Denmark's most important literary award, the Hans Christian Andersen Literary Prize in 2015. Murakami is also the recipient of honorary degrees from the universities Princeton and Liège. Therefore, it is not an exaggeration to say that in the global literary landscape, Japanese literature's contemporary face is that of novelist Haruki Murakami. ${ }^{1}$

Interestingly, Murakami had no close associations with anyone from the bundan or the Japanese literary establishment when he started to write. He was not a member of any writer's group and he did not have any acquaintance who was part of the establishment. Yet, when he completed his first novel, he immediately sent it to Gunzo literary magazine that maintains a contest for upcoming writers. In the 1990s, even when he became established as an author, Murakami still chose to distance himself from the bundan and the local media.

Murakami has this to say about his early relationship with the Japanese literature of his age: "I had never taken a serious look at contemporary Japanese fiction. Thus, I had no idea what kind of Japanese novels were being read at the time, or how I should write fiction in the Japanese language" "The Birth" x). Naturally, without an affinity for Japanese literature, Murakami had to develop a style of writing for his own literary vision. It was this individual literary vision that facilitated his acceptance by the global market.

Murakami criticizes Japanese writing to be "very stiff" (Deveraux, "PW Interviews"). This seriousness is the expectation set by the public for authors. It also appears that the stiffness has something to do with the Japanese language which has a strong hierarchical nature. Therefore, the reason behind Murakami's innovation of the Japanese language is clear-he wanted more freedom in his prose. He said, "I am different in my style. I guess I'm seeking a new style for Japanese readership, and I think I have gained ground. Things are changing now" (DiConsiglio 15). This linguistic style suited the global culture and its readers.

But Murakami sought exile abroad when he became famous in Japan. Murakami's visiting fellowships in universities abroad during that period, 
while providing him a more relaxed atmosphere to mingle with the Western literati and thus gain footage in an international network, also created some fear in him. Whether in his country or abroad, he still felt like an outsider in the field of literature. He shares:

I'm a loner. I don't like groups, schools, literary circles. At Princeton, there was a luncheonette, or something like that, and I was invited to eat there. Joyce Carol Oates was there and Toni Morrison was there and I was so afraid, I couldn't eat anything at all! Mary Morris was there and she's a very nice person, almost the same age as I am, and we became friends, I would say. But in Japan I don't have any writer friends, because I just want to have...distance (qtd. in Wray 124).

Does Murakami's resistance to be part of a group and maintain "distance" help him to be a better writer? It is hard to say. Surely, with his collaborators of academic translators, New York and London-based publishing houses from the midpoint of his career to the present, he can no longer be categorized as a peripheral writer. Perhaps the distance affords him his much sought-after individualism that is one of the strongest ingredients of his fiction. Murakami may not have acquired much capital from personal relations with individuals and elite writers but his impact is perceived in terms of his relationships with two of the main sources of literary capital in the contemporary age: his publishers and his sought-after translators of Japanese to English.

Murakami gave his impressions of the American publishing world in an essay found in the Japanese volume of his short story collection "The Elephant Vanishes" where he says:

[They] may have a reputation as being real sticklers for contracts, but I've found that it's mostly a stereotype. From my own experience, most agreements are sealed with a single handshake. It's a world built on personal trust...In fact, I feel that the American publishing world is probably more human than the Japanese one. In Japan editors sometimes come off as 'publishing company employees' who hold adhering to the 'company logic' more dear than their relationship with an author" (qtd. in Templado, "Teamwork Helped"). 
Murakami's fruitful relationship with his US-based Murakami, Inc. as well as his long relationship with his Japan-based Murakami, Inc. ${ }^{3}$ are some of the most important aspects of his success that has helped him dominate the literary fields inside and outside Japan. To add more to his literary capital, apart from writing novels, Murakami has not only written short stories, travel writing, a memoir, but has also experimented with a type of non-fiction writing when he interviewed the survivors of the fatal Aum Shinrikyo Sarin gas attack in the late 1990s. He has also been the subject of a BBC One documentary and his fiction has been dissected in varied symposia in universities across the globe. Moreover, he also works as a translator of American literature into Japanese. It is clear therefore that in Japan, Murakami occupies a privileged position as a professional writer who enjoys both a serious (as attested by critical acclaim and awards bestowed upon his work) and popular (as proven by his book sales) position. Outside of Japan, Murakami has become recognized as the leading Japanese fictionist of his age and occupies the unique position of being both a serious author and a popular writer. Mori attests: “...younger readers can enjoy the strengths of his storytelling, and they may even unwittingly absorb some of his masked meaning" (220).

However, distinction for a writer like Murakami who sets himself apart from the other writers or social agents of the literary field comes with attacks from competing players in the game of literary production. In Japan, Murakami's popularity does not spare him from the harsh questioning from the bundan for his objectives in writing fiction. Even when he had already established himself as a bestselling author with an increasing number of awards, Murakami's fiction is criticized by members of the bundan for its Western influences. John DiConsiglio reports how some critics would refer to his work as batakusai which literally means "stinking of butter" or to be more specific, too Westernized or Americanized. This evaluation of his work led him to be ostracized by the literary establishment in the early years of his writing. Murakami shares: "I took a lot of heat when I launched my career thirty-five years ago. "This can't be called a novel," older critics fumed. “This isn't literature!” I found the constant attacks quite depressing, so I left 
Japan for a number of years and went to live abroad, where I can write what I wanted in peace, free of the constant static" ("The Birth" 77).

\section{The Bundan in the Age of Global Literature}

In Hideo Furakawa's interview with Haruki Murakami, Murakami recalled what the literary establishment was like when he started as a writer:

[i]n those days, writers, critics, and editors all belonged to groups that functioned rather like clubs. If you didn't join one of these clubs, you inevitably felt a kind of isolation. It wasn't that I was opposed to this literary establishment, but I disliked the pressure to socialize, so I kept to myself. The problem was in their world you were either friend or foe, whereas my basic philosophy was to seek neither, which meant I ended up surrounded by almost nothing but enemies (69).

From the Meiji period (1868-1912) to the Taishō period (1912-1926) and even to the Showwa period (1926-1989), the Japanese literary aesthetic was mostly controlled by the bundan. El-Khoury points out that the term bundan has been used in two different ways:

on the one hand it referred to literary circles in a broad sense and could include anyone who wrote or criticized literature; on the other hand, it referred in a narrow sense to specific literary people, and bundan bungaku refers exclusively to works produced by the group. Like junbungaku, bundan is an elusive term whose meaning must be grasped by gathering fragmentary information from different time periods (37).

Angela Yiu explained that the word bundan can be loosely translated as "literary circle." She said that it is a mostly Tokyo-based group of writers, critics and publishers (magazines included) that set the criteria for literary works. They also promoted certain writers and engaged in a conglomeration of writing activities. Over the decades of its existence, the bundan has had many changes in its form and operation. Some of these changes happen incrementally, while others come hastily. Yiu explained that major figures like Mori Ogai (1862-1922) who introduced changes in Japanese poetry, ${ }^{4}$ and the writer Kikuchi Kan (1888-1948) who founded a publishing house 
and the magazine Bungeishunju which awards the Akutagawa Prize, ${ }^{5}$ are two of the people who directed literary productions for a certain period. Ogai and Kan are therefore individuals who were (almost single-handedly) able to introduce a big change in the literary field during their day. Murakami appears to be the next individual to do such.

With the wave of literary influences coming from outside Japan, the Japanese aesthetic understandably has become a collection of old models and new, appropriated strategies and interpretations that are palatable to the Japanese literati. Due to internationalization, followed by late-capitalist globalization, what then in the Meiji era was a "wave of influence" of outside forms of literature became a hurricane of changes that contemporary Japanese authors and critics had to grapple with. The changes in the literary milieu, of course, take place in a society that also changes. Awards and recognition may still have symbolic value in the world of literature; however late-capitalism has proven that sales have increasingly mattered and become equal with awards.

In the new millennium, Yiu has noticed that the bundan is drifting towards popular literature: "in the sense that in order to sell anything you need to reach a large market" (personal interview). This is very different from how traditional support for a literary work is provided. Ideally awards and recognition are given out to writers whose works achieved the standards set by the bundan. The standards are interpretations of what the bundan calls Pure Literature (junbungaku) - a pure type of literature that developed from the cultural specificity of Japanese-ness.

However, today, even Japan's two biggest literary prizes, the Akutagawa Prize and the Naoki Prize ${ }^{6}$ have reflected the noticeable commercial thrust of the contemporary bundan. Yiu points out that recent winners of the Akutagawa Prize do not represent junbungaku or pure literature. A lot of times, she said, it is the literature that appeals to a broad readership that wins the award. Therefore, the distinction between the writers who win the Akutagawa Prize or the Naoki Prize becomes blurred. It can be said then that Japan's literary field and its key players (which include award giving bodies), just like literary fields elsewhere, have bent to the demands of the 
market economy. Changes in the genres and the production of literature are influenced by market forces.

Yiu stressed the importance of publishing houses and the media in Japan's current literary field. She also adds that winning awards is an auspicious situation for authors to increase their book sales:

...the publishing houses and the media... are very important in promoting the direction of literature, and there are also, aside from the Akutagawa and Naoki prizes, there are many, many different types of literary prizes awarded to the new writers or experienced writers. Once you receive a prize the sales of your book go up, at least right around the time that you get the prize and then some people would ride on that moment of success and [as a result] become more successful with the sales of their publication going up. And then for some people it is just a momentary success, so I think that's what you're looking at with the bundan (personal interview).

Clearly in the contemporary age, Japanese literary prizes are intertwined with the demands of the market economy. Award-winning authors are not only given the prestige that the award carries, but they are also launched to a public of reader-consumers who are looking for the next big thing in the literary world. If the writers are not able to sustain the interest of their fickle public, the attention and book sales that are provided to them soon dies down and they are replaced quickly by other literary stars.

Murakami was able to sustain a high level of critical acclaim and book sales which continued decades after he started writing. Yet, Murakami attributes his success to his readers more than the publishers and other industry workers. ${ }^{7}$ Moreover, despite the success in book sales he has outside and inside of Japan, he still feels a bit of the isolation he felt when he began his work as a writer. Even today, Murakami laments that he is an outcast of the Japanese literary world: "I have my own readers ... But critics, writers, many of them don't like me. Why is that? I have no idea! I have been writing for 35 years and from the beginning up to now the situation's almost the same. I'm kind of an ugly duckling. Always the duckling, never the swan” (Poole).

Murakami's situation has been described by him as "almost the same" but tracking his career there have been some favorable changes bestowed 
upon him, such as the acceptance by one of his former staunchest critics, the Nobel Prize winner, Ōe Kenzaburo. Ōe previously found Murakami and his works too apolitical-to him Murakami's works then were "sophisticated stylizations of trivia" (Napier 204). To Roland Kelts, the big turnaround in Ōe's attitude towards Murakami occurred when Murakami wrote and published the novel The Wind-up Bird Chronicle in the mid-1990s. For this work Murakami received the Yomiuri award for literature, one of the biggest, highly respected awards in Japan, and the award was conferred upon Haruki by Ōe. Ōe praised Murakami when he gave him the award, noting that this is a novelist who is dealing with big social issues: Japan's war-time history and Manchuria. Heavier historical issues that appeared in that book really changed the minds of certain members of the bundan including Ōe, who later in an interview was very extensive in his praise of the work (Kelts, personal interview).

In an interview where Ōe was asked if he felt competitive toward writers like Murakami, he said:

Murakami writes in a clear, simple Japanese style. He is translated into foreign languages and is widely read, especially in America, England, and China. He's created a place for himself in the international literary scene in a way that Yukio Mishima and myself were not able to. It's really the first time that has happened in Japanese literature. My work has been read, but looking back I'm not sure I secured a firm readership, even in Japan. It's not a competition, but I would like to see more of my works translated into English, French, and German and secure a readership in those countries. I'm not trying to write to a mass audience, but I would like to reach people (Fay, "Interview: Oe Kenzaburo").

Ōe's acceptance of Murakami and his pivotal role in Japanese literature has signaled an important change on how the bundan views acceptable literature. From the interview it can be culled that Murakami's mass readership, a sign of his being a popular author, does not diminish his role in being a representative of contemporary Japanese literature. Although Ōe himself does not want to be a popular author, he is clearly astounded with the global influence of Murakami through his international following. 
With his acceptance by Ōe, Murakami himself recognizes that the Japanese literary field has come to change over the decades. He recognizes that the literary game played in Japan is different from the literary game outside of it. He states: "[b]ut I think, in a sense, we are playing different games...I began to think that way. It's very similar, but the rules are different. The equipment's different, and the fields are different. Like tennis and squash" (Fay, "Interview: Oe Kenzaburo"). Indeed, Murakami's strategy in playing the literary game is quite different from Japanese writers who only seek to be read by national readers. Clearly, Murakami's strategy in playing the literary game is to gain some influence or capital within and outside the Japanese literary establishment. To a large degree he has accumulated capital through his texts being translated into English, yet he still encounters stringent critics whom he still was not able to appease over the years.

Asked by an interviewer if winning the Nobel Prize would solve his problem with his Japanese critics, Murakami humorously replied: “...I don't want to speculate... That's a very risky topic. Maybe I would be hanged from a lamp post. I don't know!" (Poole, "Haruki Murakami”). As Tim Parks writes, "the [Nobel winner's] status is transformed, and his work transfigured from contemporary to classic" ("The Nobel Individual”).

In Bourdieusian terminology, the Nobel Prize is the ultimate symbolic capital that authors may receive in their lifetime.

Winning the third Nobel Prize for Japan may be the ideal of many Harukists (Haruki readers or fans), but the ultimate international literary award does not resonate with what Murakami wants for his own literary career. For one, he is known to value his readers' expectations more than his critics. Part of his agenda when writing a book is to be read by a mass readership (which today gives his works a high commercial value), hardly the goal of a serious literary author in any national literary field (Kelts, personal interview). Nevertheless, with the changing times even the Nobel Prize may soon find itself swayed by the forces of market economy just like what happened in so many national literary fields such as the case of the Japanese literary field that has gone through monumental changes after the Second World War. 
The Nobel Prize for literature has always been associated with a slew of controversy in relation to its choice of winner. In 2011, the former chair of Nobel Prize in Literature and Nobel committee member Kjell Espmark discussed the Nobel selection process in a forum hosted by Harvard University. Espmark told his audience that the criteria for selecting the winner has changed since the Swedish Academy began to award the title in 1901. There was a period when the committee chose popular literature and, in another time, they chose a writer who had a literary humanist idea. Espmark emphasized that the committee is not swayed by politics in the selection of the awardee; he cited the instance of the writer Alexander Solzhenistyn who won the award in 1970 despite the protest of the Soviet Union (Chen, “Author Demystifies”).

As much as the current Japanese literary field would welcome another Nobel winner, Dreux Richard does not believe that it is Murakami who should be the chosen one for the award. Richard writes that Murakami:

...has avoided the difficult, unrewarding work that surmounting cultural barriers demands: writing multilingual texts that defy commercial literary paradigms. This has been left to Yoko Tawada, Hideo Levy, Minae Mizumura and Lee Yangji, among others, all of whom have labored under the sign of Japan's last Nobel caliber author, the late Kenji Nakagami ("Why Haruki Murakami”).

For Richard, just like Murakami's other critics (which includes the literary critics Masao Miyoshi and Yoichi Kimori and the philosopher Kojin Karatani), he is not Japanese enough; moreover, he is too commercial. These criticisms have been constantly hurled at Murakami since the start of his career and yet Murakami has prevailed over the decades as a writer of Japan and as a translated author overseas. This is because Murakami and his fiction resonate with today's notion of what literature is.

\section{Murakami as a Japanese Writer in the Global Age}

Tim Parks in his article "The Nobel Individual and the Paradoxes of International Literature" shares the following about literary success today: 
[a] novelist is not famous today unless internationally famous, not recognized unless recognized everywhere. Even the recognition extended to him in his home country is significantly increased if he is recognized abroad. The smaller the country he lives in, the less important his language on the international scene, the more this is the case. So, if for the moment the phenomenon is only vaguely felt in Anglophile cultures, it is a formidable reality in countries like Holland or Italy. The inevitable result is that many writers, consciously or otherwise, have begun to think of their audience as international rather than national.

What Parks discusses here is the marked growing consciousness of writing for an international audience by contemporary writers, especially those writers from "smaller countries"-and by this Parks means not only in size but also in terms of capital ("The Nobel Individual"). Thus, to write for an international or global audience increases the chance for the writer to receive distinction as a writer. What Parks has pointed out describes the current global literary field where translation into a highly regarded language such as English is of primary importance. Parks wrote his article for The Times Literary Supplement in 2011. Yet, interestingly, it is this model of global literature described by Parks that has been followed by Murakami as early as the 1990s when his works were first translated into English. This model that addresses an international or global audience rather than just a national one has served Murakami well. He is able to earn distinction from his Japanese audience since he is still a Japanese language writer, an increasingly highly regarded one at that; and then, he is a translated author with a solid support group overseas-his US-based Murakami, Inc. The critics in both literary fields indeed have noticed his contribution to both Japanese and Global literature.

The more awards Murakami amassed, the more he asked himself questions about his role in the literary fields of Japan and the world. He began to reflect on his choices as a writer, whether he would just maintain commercial sales as the indicator of his success or whether he would probe deeper and look for other areas of literary legitimation. He shared, 
...I myself have [a] hard time understanding how I made it this far. I didn't have my heart set on becoming a novelist when I was young, nor did I follow a series of steps to earn my spurs-no special studies, no training, no piling up of notebook exercises. Like so many things in my life, events seem to follow on their course, pulling me along. Luck played a big part too. It's rather unnerving when I look back now, but there's no way around it-that's the way it was" ("So What Shall" 68).

Murakami's popularity and critical acclaim can then be a sign of an emergence of a new age of Japanese writing. What exactly did Murakami introduce? For one, Murakami's Japanese writing style is more colloquial and makes use of a lot of borrowed English words (making his works easily accessible to the Anglophone translator); second, his writings contrasted heavily with popular writing of the 1960s and 1970s because he did not pursue the realistic mode and opted to use fantastic elements in his stories; and third, his early writings appear to be apolitical and individualistic. Although Murakami had a growing following in Japan and (although with some hesitation from some members of the bundan) literary doors were opening for him, Murakami felt constricted in Japan and decided to continue writing abroad where the global literary field, beginning with its located center which is the US, welcomed him. In 1991, Murakami and his wife left Japan for the US where he became a visiting writer at Princeton University.

At this point it must be noted that when Murakami left for the US he was already a writer with distinction. He was an upcoming writer who sold millions of copies of his Norwegian Wood and at the same time he had some critical acclaim. When asked why he had to move to the US where he chose to live and write he said that he wanted to escape Japan particularly its literary establishment: "[a]t that time, the literary establishment in Japan still exerted considerable influence. They had...how shall I put this...the power to lay down the law, so to speak, and if you went against them, well, they could make things pretty difficult. I get the feeling, though, that the situation has changed" (Furukawa 69).

The move to the US, although risky, helped him gain more symbolic capital as a writer and it also allowed him an entry point to gain prestige 
in the bigger US market. It can even be said on hindsight that Murakami's calculated risk of entering the bigger global literary establishment spearheaded by the US literary workers, while maintaining an ambivalent relationship with his local literary establishment, was unconsciously strategic in creating his name in the global literary field.

Murakami did not completely disengage himself from Japan though. For him the year 1995 was life-changing. He was living in the US at the time and interestingly he compares his experience to that of F. Scott Fitzgerald when the Great Depression hit the United States. Fitzgerald was then in Paris and he made the decision to return to America because he felt it was his responsibility as an American to return to the United States when it was suffering; Murakami felt very much the same way about Japan when the Kobe earthquake and the Sarin gas attack occurred in 1995 that he went back to Japan to try to understand what was happening (Williams, "Marathon Man"; Brown, “Tales of the Unexpected”).

His two-volume nonfiction Underground or Andagurando is the result of his decision to be in his home country during a time of social crisis. The work involved interviews he conducted with his fellow Japanese who were either the victims of the gas attack or the perpetrators of the attack. The latter were part of the Aum Shinrikyo (Supreme Truth) cult. Murakami said that the experience of writing that book really changed him as a writer and as a person-as a Japanese person. He shared: "[t]he victims were hard-working people who served their companies... For a long time I was not interested in that kind of person, but after those interviews I sympathized with them. I could understand what they are and how they live. That recognition changed me somehow" (Williams, "Marathon Man"). In addition to producing his nonfiction Underground, his research on what happened, especially on the cult, would later figure in his novel 1 Q84.

\section{Conclusion: Overcoming the Murakami Brand of Literature}

The case of Haruki Murakami's rise to dominance in both the Japanese and global literary fields is truly exceptional. It is rare that a single author has introduced so much innovation in a literary field in his own lifetime. 
However, due to the fruitful combination of Murakami's own talent, the cooperation of his literary collaborators, Murakami, Inc., the advancement in technology (i.e., the Internet) that has allowed Murakami to be in touch with his readers, and his exceptional understanding of English, Murakami has contributed much to Japan's contemporary literature in the age of global literature. In addition to these factors, it must be emphasized that Murakami's agency of transforming the conservative literary field of Japan into something more accessible to both the Japanese and the non-Japanese has made Murakami a force that has also transformed Japan's Post-World War, modern literary field into a field that is open to accommodate postmodern techniques in writing, reflective of its historical position or context and global in its reach.

The success of Murakami's fiction has resulted in his acquisition of different types of capital and an expansion of his habitus. He has become an author of the emerging global literary field. As a testament to the effectivity of his "branding" as a global author, he has been the subject of both academic and popular media's inquiry. He also has been legitimized as an author through the awards he has been given.

What began as a fascination for Western fiction which Murakami tried to mimic in his own writing over the years gave birth to a writing style now described as Murakamiesque. This Murakami style of writing (which is captured even in translation) along with Murakami's trademark themes of alienation, historical revisionism, the critique of urban life, and the unmasking of society's dark side have become Murakami's literary contributions that aim to capture humanity's ethos in the twentieth to the early twenty-first centuries.

Murakami perfected his Murakamiesque style which gave his literary works a "brand" that his loyal readers support in terms of book sales. Thus, Murakami through his style and content was initially able to create a specific literature which made use of similar postmodern techniques from Anglophone writers. This Murakami brand of writing is still evolving especially since Murakami has been consciously putting in more Japanese social issues in his fiction. With his comprehensive novel, 1Q84, for instance, Murakami began 
making his Japanese identity and concerns more pronounced while synthesizing these with his Murakamiesque style.

Unlike earlier writers of serious Japanese literature who looked at their writing as an art form, Murakami sees his writing life as a profession. Although Murakami clearly writes serious novels, he targets the literary taste of his readers as the standard of his writing, rather than those of the award-giving bodies for legitimation. That he writes for his reader's appreciation and entertainment is a claim that Murakami often makes. Thus, it makes sense that Murakami would see his stories and himself as an author as “assets." Unlike writers from the bundan, Murakami does not hide the fact that he is a professional writer concerned with book sales.

While Murakami was writing his Western-influenced fiction overseas and was accumulating literary capital through awards and book sales, Japan as a nation had its own issues to contend with. On a national level, the 1990s brought about Japan's biggest economic recession; it also was a time of social unrest heightened by the religious cult Aum Shinrikyo's gas attack that proved that Japan's prosperity was not able to address issues pertaining to the psyche of the Japanese people. Postwar Japanese are perceived to lack a deeper purpose in their lives after they have reached economic prosperity. The old community spirit has been abandoned in the impersonal big cities such as Tokyo. Murakami was quick to sense this and used his fiction to unveil often hidden aspects of Japanese society and history.

As of this writing, Murakami remains a formidable force in the world of literature and yet the literary world must overcome the enigma of Murakami. Young writers must challenge Murakami’s legacy. This is what Murakami did himself when he started writing, he challenged the bundan. Now, as expected, Murakami has become part of the very institution that he challenged decades ago. Young writers, may they be Japanese or from around the globe, must continue Murakami's legacy and overcome it by creating their own identity.

In his own country, literary workers are busy looking for the next big thing after Murakami. Contemporary Japanese writing is fighting an uphill battle to be recognized outside of Japan. Thus, the Japan Foundation has 
come up with a list of literary works that they are promoting overseas in order for translators to pick up new works. The booklet called Worth Sharing: A Selection of Japanese Books Recommended for Translation has been published annually since 2012. It is indicated in the booklet that translators may receive support for their translation work "provided the translations are of adequate quality and appropriate plans are submitted" (1). Below is how the Foundation explains the need for such a booklet of recommended works for translation:

In 2012, we undertook a new initiative aimed at giving people overseas a better understanding of contemporary Japan through recommendation of selected outstanding books for translation. Creating these lists is a way for the Japan Foundation to help spread the word about brilliant books that depict what the nation is like now, providing readers with authentic views of Japanese society and its people. Our lists are drawn up around general themes, providing perspectives on social and cultural undercurrents, making them guides to writing in Japan that are accessible even in regions and languages in which contemporary Japanese books are not particularly well known. When Japan is viewed from multiple perspectives or angles, it offers up new dimensions and colors. Our goal in creating these themed lists is, over time, to convey aspects of culture and society that cannot be grasped through a one-dimensional approach (1).

One of the committee members who selected literary works for inclusion in the booklet is Nozaki Kan, a professor at the University of Tokyo. Nozaki in his introduction to the list states that: " $[\mathrm{t}]$ here are no works by Murakami Haruki, but this is simply because he already has an overwhelming level of international recognition. Readers will likely come to a vivid realization of the diverse brilliance of contemporary Japanese literature that lies hidden in the shadow of Murakami's immense popularity" (3). Kan is correct; for Japanese literature to thrive in the global age, Japanese literature must overcome Murakami’s legacy.

Overcoming Murakami's legacy appears not only of interest to the remaining Japanese bundan or literary workers for the benefit of their fellow Japanese. It appears that the Japanese bundan has now taken interest in actively engaging or educating foreigners toward a better understanding of 
the pillars of Japanese literature before and beyond Murakami. Yet, for now, they are capitalizing on the popularity of Murakami to create and enrich interest, not only in newer texts and authors, but older texts and authors as well. A recent example of such an initiative is The Asahi Shimbun's call for entries to an international essay contest on Natsume Soseki. According to the contest notice:

The Sōseki International Essay Contest is inviting entries on the continuing appeal of his works among foreigners. Sōseki, one of Japan's most famed and popular authors, lived in the period of transition to the modern society... Sōseki's works had a major influence on Haruki Murakami, who is a representative author of contemporary Japan (italics added).

It appears that Murakami has already reached the level of Sōseki in terms of his impact on Japanese literature. Will he have a long-lasting impact on global literature? Murakami has already reached global recognition that may have already cemented his status on a national level in Japan. In time it will be recognized whether Murakami's works will endure globally to reach the level of the classic. What is assured right now is that Japanese literature of the late twentieth to the early twenty-first centuries will always include in its discussion the fiction of a writer from Kobe who wrote his early novels on his kitchen table. 


\section{Notes}

1. Murakami has spawned a dozen novels, three short story collections, travel writings, and non-fiction prose, in addition to numerous translations. However, it is his work as a novelist that has reaped him consistent recognition.

2. This was changed in the latter part of his literary career. In 2006, Murakami wrote an introduction to Rashomon and Seventeen Other Stories, by Ryunosuke Akutagawa showing that he in fact continues to read and actively participate in discussions on Japanese literature. The collection was translated by one of Murakami's own translators, Jay Rubin. Here, according to Mori: "Murakami considers which writers qualify as the ten most important 'Japanese national writers' since the Meiji Restoration in 1868..." (215).

3. Although he criticizes the Japanese bundan, Murakami has a long-spanning relationship with its members. He himself, as Prof. Angela Yiu mentioned in a personal interview, is in fact part of it already. Interestingly, his novel 1Q84 also contains multiple references to the bundan and how it operates.

4. Ogai composed 232 kanshi, or Sino-Japanese poems, that were published in a two-volume anthology. These poems show his provocative US of literary devices, particularly, allusion. Moreover, these poems show his mastery of kanji (Wixted 89).

5. "The Akutagawa Prize, named after the fictionist Akutagawa Ryūnosuke, is one of the two most prestigious literary prizes in Japan. As of 2011, 260 prizes have been awarded officially for junbungaku tanpen. Though in reality short novels/ novellas win most often (El-Khoury vii).

6. The Naoki Prize is another literary prize founded by Bugeishunjū Ltd., in commemoration of novelist Naoki Sanjūgo (1891-1934). This award is given to promising writers of taishu bungaku (popular literature) (El-Khoury viii).

7. Venuti states that "various factors play into the reception of any book, in addition to imponderables which guarantee that any prediction of success or failure can never be certain" (162). 


\section{Works Cited}

Akutagawa, Ryūnosuke. Rashōmon and Seventeen Other Stories. Translated by Jay Rubin, Penguin Books, 2006.

Bourdieu, Pierre. The Rules of Art: Genesis and Structure of the Literary Field. Edited by Werner Hamacher and David E. Wellbery and translated by Susan Emanuel, Stanford UP, 1996.

Brown, Mike. “Tales of the Unexpected.” The Telegraph, 15 Aug. 2015. Web. Accessed 1 Jun. 2016.

Chen, Wendy K.X. "Author Demystifies Process Surrounding Nobel Prize.” The Harvard Crimson, 15 Apr. 2011, https://www.thecrimson.com/ article/2011/4/15/espmark-prize-nobel-swedish/. Accessed 13 Apr. 2012.

Deveraux, Elizabeth. “PW Interviews: Haruki Murakami.” Publisher's Weekly, 21 Sept. 1991, http://gbctrans.com/eotw/pubweekly.html. Accessed 13 Apr. 2012.

DiConsiglio, John. "Haruki Murakami Stinks." Literary Cavalcade, 15 Jan. 1999, Web. Academic Source Complete. Accessed 7 Apr 2009.

El-Khoury, Masumi Abe. "Editors' Intentions and Authors' Desires: How Junbungaku Affects the Akutagawa Prize and Japan's Commercial Literary World." 2011. University of British Columbia at Vancouver, MA Thesis.

Facebook.com. "Haruki Murakami Author." https://www.facebook.com/ harukimurakamiauthor/.

Fay, Sarah. "Interview: Oe Kenzaburo, The Art of Fiction No.195," The Paris Review, 14 Oct. 2014, https://www.theparisreview.org/interviews/5816/ kenzaburo-oe-the-art-of-fiction-no-195-kenzaburo-oe.

Furukawa, Hideo. "Pursuing 'Growth': An Interview with Murakami Haruki by the Novelist Hideo Furukawa.” Monkey Business: New Writing from Japan, translated by Ted Goossen. 1. 2011, pp. 65-115. (Interview conducted on 16 Dec. 2008 in Tokyo).

Hockx, Michel, and Ivo Smits, editors. Reading East Asian Writing: The limits of literary theory. RoutledgeCurzon, 2003.

Kelts, Roland. Personal interview. 14 Oct. 2009.

Mori, Masaki. "Murakami Haruki’s Canon." Southeast Review of Asian Studies, 34, 2012, pp. 215-21.

Murakami, Haruki. A Wild Sheep Chase: A Novel. Penguin Books, 1990.

---. "So What Shall I Write about?" translated by Ted Goossen. Monkey Business: New Writing from Japan. 5: 2015, pp. 68-78.

---. "The Birth of My Kitchen Table Fiction: An Introduction to Wind/Pinball: Two Novels." Wind/Pinball: Two Novels. Translated by Ted Goossen. Bond Street Books, 2015.

Oxnam, Robert. "Classical Japan," Asian Topics: An Online Resource for Asian 
History and Culture. 15 Aug. 2015. http://afe.easia.columbia.edu/at/cl_japan/ cj05.html.

Parks, Tim. "The Nobel Individual and the Paradoxes of International Literature," The Times Literary Supplement. 20 Apr. 2011.

Poole, Steven. "Haruki Murakami: 'I'm an outcast of the Japanese literary World." The Guardian. 13 Sept. 2014. https://www.theguardian.com/books/2014/ sep/13/haruki-murakami-interview-colorless-tsukur-tazaki-and-his-years-ofpilgrimage. Accessed 13 Sept. 2014.

Project Dystopia. "Haruki Murakami: In Search of This Elusive Writer." YouTube, 23 Nov. 2011.

Richard, Dreux. "Why Murakami Haruki should not receive the Nobel Prize for Literature." Japan Today. 10 Oct. 2012. https://japantoday.com/category/ features/opinions/why-haruki-murakami-should-not-receive-the-nobelprize-for-literature. Accessed 15 Sept. 2011.

Shirane, Haruo. "Canon Formation in Japan: Genre, Gender, Popular Culture and Nationalism." Reading East Asian Writing: The Limits of Literary Theory. Edited by

---. "Mediating the Literary Classics: Commentary and Translation in Premodern Japan." Rethinking East Asian Languages, Vernaculars, and Literacies, 1000-1919. Edited by Benjamin A. Elman, Brill, 2014.

Staines, Judith. “Murakami Wins International Catalunya Prize.” ASEF Culture360. 11 Jun. 2011. https://culture360.asef.org/news-events/murakami-wins-international-catalunya-prize. Accessed 15 Sept. 2013.

Templado, Louis. "Teamwork Helped Haruki Murakami Break into American Scene." The Asahi Shimbun. 30 Nov. 2014. http://ajw.asahi.com/article/behind_ news/people/AJ201404180044. Accessed 30 Jun. 2015.

The Asahi Shimbun. "Entries Sought from Foreigners for Essay Contest on Soseki," 4 May 2016. http://www.asahi.com/shimbun/sosekiessaye.html. Accessed 6 May 2016.

The Independent. "Japanese Writer Murakami Honoured in Spain," 5 Dec. 2009. https://www.independent.co.uk/arts-entertainment/books/news/japanesewriter-murakami-honoured-in-spain-5510876.html. Accessed 13 Jul. 2015.

Williams, Richard. "Marathon Man.” The Guardian. 17 May 2003. https://www. theguardian.com/books/2003/may/17/fiction.harukimurakami. Accessed 20 Jun. 2009.

Wixted, John Timothy. "The Kanshi of Mori Ogai: Allusion and Diction." Japonica Humboldtiana, 14, 2011, pp. 89-107.

Worth Sharing: A Selection of Japanese Books Recommended for Translation. Vol. 3: Illuminating Love in Japan. Tokyo: The Japan Foundation, 2014. Wray, John. "Interviews: Haruki Murakami, The Art of Fiction No. 182." The 
Paris Review, 170, 2004. 26 Feb. 2009. https://www.theparisreview.org/ interviews/2/haruki-murakami-the-art-of-fiction-no-182-haruki-murakami. Yiu, Angela. Personal Interview. 11 Oct. 2009.

Ynet News.com. Japanese Author Murakami Wins Jerusalem Prize, 1 Jan. 2009. https://www.ynetnews.com/articles/0,7340,L-3660005,00.html. Accessed 5 Jan. 2009. 